\title{
Comparing wheat flour and commercial wheat extract skin prick testing in Wheat Dependent Exercise Induced Anaphylaxis
}

\author{
Lana A Rosenfield ${ }^{1 *}$, Chrystyna Kalicinsky ${ }^{2}$ \\ From Canadian Society of Allergy and Clinical Immunology Annual Scientific Meeting 2010 \\ Victoria, Canada. 3-6 November 2010
}

\section{Background}

Wheat Dependent Exercise Induced Anaphylaxis (WDEIA) is a form of Food Dependent Exercise Induced Anaphylaxis. WDEIA occurs when there is an allergic reaction following the ingestion of wheat, coupled with exercise [1]. The suspected allergen that is responsible for WDEIA is omega- 5- gliadin [2].

We report a series of adult clinical cases of WDEIA recorded between 2006-2009 at Health Sciences Centre (Winnipeg). The purpose of this study was to compare the results of Skin Prick Test (SPT) to commercial wheat extract and wheat flour in patients with WDEIA.

\section{Materials and methods}

We preformed a retrospective chart review of 8 patients with WDEIA. We recorded response to SPT for commercial wheat extract (Omega, Allergy Canada) and wheat flour.

\section{Results}

The patients were 25-63 years old, 5/8 were female. All patients had histories of wheat consumption followed by exercise (or stress) resulting in allergic reactions. 5/8 cases were SPT negative to commercial wheat extract but positive to wheat flour. 1/8 was SPT negative with both commercial wheat extract and wheat flour, but positive with the wheat product (bun), which by history provoked a reaction. $1 / 8$ was SPT positive to both. $1 / 8$ was positive to wheat extract but SPT to wheat flour was not done. When patients adhered to wheat avoidant diets no reactions occurred.

* Correspondence: lanarosenfield@me.com

${ }^{1}$ Faculty of Medicine, University of Manitoba, Winnipeg, Canada

Full list of author information is available at the end of the article

\section{Conclusion}

In the 8 adults reviewed with WDEIA, SPT with wheat flour was much more sensitive than SPT with commercial wheat extract. Therefore, both commercial wheat extract and wheat flour should be used for SPT to diagnose WDEIA.

\section{Author details}

${ }^{1}$ Faculty of Medicine, University of Manitoba, Winnipeg, Canada. ${ }^{2}$ Section of Clinical Immunology and Allergy, University of Manitoba, Winnipeg, Canada.

Published: 4 November 2010

\section{References}

1. Palosuo K, Alenius H, Varjonen E, Koivuluhta M, Mikkola J, Keskinen H, Kalkkinen N, Reunala T: A novel wheat gliadin as a cause of exerciseinduced anaphylaxis. J Allergy Clin Immunol 1999, 103:912-917.

2. Lee J, Yoon S, Ye Y, Hur G, Kim S, Park H: Gliadin-specific IgE in wheatdependent exercise-induced anaphylaxis. Allergy Asthma Proc 2008, 29:614-21.

\section{doi:10.1186/1710-1492-6-S2-P3}

Cite this article as: Rosenfield and Kalicinsky: Comparing wheat flour and commercial wheat extract skin prick testing in Wheat Dependent

Exercise Induced Anaphylaxis. Allergy, Asthma \& Clinical Immunology 2010 6(Suppl 2):P3.

Submit your next manuscript to BioMed Central and take full advantage of:

- Convenient online submission

- Thorough peer review

- No space constraints or color figure charges

- Immediate publication on acceptance

- Inclusion in PubMed, CAS, Scopus and Google Scholar

- Research which is freely available for redistribution 